\title{
Student Leadership At The University
}

\author{
Ann T. Hilliard, Bowie State University, USA
}

\begin{abstract}
The focus of this article is about the utilization of student leadership at the University. Based on research, student leadership opportunities at the university have been frequently at a low percentage (Zimmerman, Burkhart, 2002). The researcher identifies practical ways to involve students in various leadership activities. Emphases are placed on the definition of leadership, characteristics of strong leadership, importance of stakeholders, early involvement, expectations of today's leaders, and benefits of student leadership at the university. The three ways to look at leadership includes a respond to an idea that the future is unknown and there is not any one model for leadership, prepare for the future by embracing and creating the capacity for change, participate in organized learning and look at collective leadership that helps in the capacity to change. There are many characteristics of strong leadership based on the needs of the organization. A strong sense of moral purpose, a clear understanding of the dynamics of change, having academic and emotional intelligence and being able to connect with people, demonstrating a commitment to developing and sharing new ideas and knowledge and being able to be coherent in the middle of chaos are some common characteristics of strong leadership. Leadership today is not the position of one individual. Stakeholders play a key role in the aim toward effective leadership at the university. Leadership is motivated by the increase complexity of university reform efforts for organizational improvement. There is a need for more individuals to participate in the reform effort to ensure greater university success. The role of university leaders and partnerships is to identify, promote and develop student leadership skills. Stakeholders are key individuals within the university's leadership system. These stakeholders are frequently identified as alumni, community leaders/supporters, faculty, staff, students and parents. Students' early involvement in leadership activities provide opportunities for volunteer services, internships in experiential activities, collaborative activities as group projects, engagement in services related to civic activities, assisting faculty in conducting workshops and university assessment and working with other students to create a community of inclusive learners on various tasks. Today, students are expected to demonstrate effective time management, show ability to set goals, build positive relationships, use effective conflict resolution skills, show an interest in helping others to build their leadership skills, become involved in community action programs and promote understanding and respect across racial and ethnic groups. Over fifty-five students participated summer 2009 in leadership workshop opportunities at a large land grant university in the mid-west of the United States of America. Students stated that the workshops were beneficial, because the workshops helped students to improve ability to set goals, show more interest in developing leadership skills in others, gain a sense of personal clarity and their own values, gain improved conflict resolution/ better decision making skills, deal better with complex and uncertainties, willing to take on more risk and are able to use leadership theories and practices in an meaningful manner.
\end{abstract}

Keywords: Student leadership, stakeholders, university reform

\section{FOCUS FOR THIS PAPER}

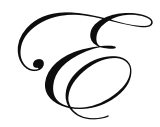

mphases are placed on the definition of leadership, characteristics of strong leadership, importance of stakeholders, early involvement, expectations of today's leaders, and benefits of student leadership at the university.

\section{DEFINITION}

There are many definitions for leadership; however, a simple meaning of leadership is the art of motivating a group or team of people to work toward a common goal based on the needs of the organization or university.

To make it simple, the leader is the individual who is capable of inspiring and directing the action to reach an identified goal short, intermediate and long term. The leader is the individual that possesses the ability to 
motivate, collaborate with others, having the appropriate skills, knowledge and attitude to move the organization toward greatness. The leader's personality is also persuasive enough to get others to follow him or her toward full filing the goals of the organization.

Frequently, the terms "leadership" and "management" are interchangeable by referring to an organizational managerial structure or to individuals who are actually managers as the "leaders" of various management teams or groups.

\section{CHARACTERISTICS OF STRONG LEADERSHIP}

To be an effective leader is to be able to manage the resources at his/her disposal, demonstrates strong sense of moral purpose and has an understanding of the dynamics of change. Effective leaders have emotional intelligence and can connect easily with others as people in building relationships. Being a strong leader, an individual shows commitment to developing and sharing new ideas and knowledge. The real test of strong and effective leadership is when the leader is able to make sure that team members are focused and are moving in a meaningful direction within the organization (Fullan, 2002).

Is a leader born or made? While there are people who seem to be naturally endowed with more leadership abilities than others. However, the author believes that people can learn to become effective leaders by concentrating on improving their particular leadership skills and being mentored by an experienced and effective leader in the profession. The researcher further believes that personality traits and the ability to think, share and pair as a leader with others is another effective way to improve and/or grow into the status of strong leadership.

Strong leaders command excellence. For a leader to reach excellence, that leader has to have good character. Character is developed over time and is formed early in life. It is difficult to determine how early character develops. Based on general research, character does not change quickly. Looking at character, is having the ability to observe a person's behavior. An individual with strong character shows high energy, determination, drive, self-discipline, will power and is a risk taker. The strong leader has to ability to attract followers and the followers become an integral part of the leadership system.

The collaborative leader must determine where the organization or university wishes to go and what will it take to get the job done. A strong leader plans strategically with the end in mind. An organization or university needs strong leaders with good characteristics and who can guide the organization to the future through a high level of trust (Marcus Aurelius, 2008)

As related to one of John F. Kennedy's thoughts, strong leaders must have courage. If the leader is effective, the organization's followers must have trust in you and must share the vision. Many organizations look for leaders that are both ethical and who can convey a strong collaborative vision toward the future. The clarity of the organization is set by the leader. The people within the organization are looking to a leader that can be trusted and one that displays good character which is exhibited by the leader's values, beliefs, skills, knowledge and traits (korn-Ferry International).

Traits differ from characteristics of an individual. Traits of a strong good leader is composed of being honest, competent, forward thinking, motivational/inspiring, fair and open minded, uses sound judgment, intelligent, and is visionary. Characteristics are geared more toward showing one's attributes, savor and virtue.

Strong leaders also have attributes related to standard bearers, integrator, and developers. A major task for the strong leaders is to establish an ethical framework within the organization or university for others and self to follow. The strong leader engages in finding ways to develop others through training, instructional /managerial services and coaching (Santa Clara University and the Tom Peters Group).. 


\section{IMPORTANCE OF STAKEHOLDERS}

Stakeholders are individuals who have a vested interest in the organization or university. Stakeholders could be alumni, previous employees, parents, spouses, career hiring companies from the public and private sector, department leaders, and others.

The engagement of stakeholders has shown to be an asset to most organization. The role of the stakeholder could be to view the organization's strength and areas needing improvement from a different set of eyes compared to others who are closest to the organization or university.

The commonalities that stakeholders share in an organization or university are to help articulate the vision, mission and strategy, commitments and implementation of that specific organization. The stakeholders are invaluable individuals, because they are able to facilitate a regulatory approvals process, often participate in measurement and reporting and are capable of averting or solving a problem that could become a crisis for the organization or university. In the area of relationship building, stakeholders can serve as a strong advocate by helping to improve the image of the organization or university. More stakeholders today are not willing to contribute much energy to processes in which they have little influence.

The engagement process by stakeholders is identified within focused groups, small group interviews, surveys for quantitative use, formal referrals, major persons' meeting/conferences, advisory council, and serving in many other ways ( $\mathrm{http}: / /$ www.ic.gc.ca/eic/site/csr-rse.nsf/eng/rs00139 ).

\section{EARLY INVOLVEMENT}

The earliest test of leadership involvement comes with the first assignment or task to manage others. College students in particular can benefit from early involvement in leadership opportunities by learning how serve as an office holder in various peer on-campus organizations. Early involvement in leadership activities will help students to have a well-recognized attitude of interest and commitment to campus academic and social life. By having knowledge and skills to influence others to follow them, these student leaders can grow to greatness in serving their communities. Students who build effective skills will be able to grow into strong and effective leadership practices as they continue to mature

As an early involvement in leadership activities, students at the university will be able to establish creditability. Credibility gives leaders the leverage of demonstrating trust and confidence in what they do as viewed by others. The First Law in Leadership, "if you don't believe in the messenger, you won't believe the message" (Kouzes and Posner, 2002). From this law, credibility is essential in respect and belief of the leader's capabilities.

\section{EXPECTATIONS OF TODAY'S LEADERS}

Leaders today are expected to create and sustain a collaborative leadership system. Leaders are expected to be able to communicate their vision about the needs of the organization through a sense of direction. A forwarded thinking leader articulates positive, optimistic and promising aspects of the future for the organization. To demonstrate competence and to work well with others is a top priority.

\section{BENEFITS OF STUDENT LEADERSHIP AT THE UNIVERSITY}

Student leaders are invaluable assets to the growth of the academic, social and cultural development of the campus environment as follows:

- $\quad$ Create a sense of ownership and responsibility.

- $\quad$ Help their peers in determining their own goals and passion for leadership

- Educate their peers in knowing the significant role that ethical leadership plays in the community at large

- $\quad$ Equip their peers with knowledge related to team building and high importance of a team

- Improve campus physically and community relations. 
- Help to coordinate meetings, write reports, communicate important information about the university

- Help to assist faculty and staff with new and improved technology on the college campus or within an organization or department

- $\quad$ Help peers to learn how to solve problems in a humane manner

- $\quad$ Increase the impact on peer educational and personal development.

- Offer peers the opportunity to grow and participate in civic community, diversity awareness and respect, improvement of social/personal values and leadership skills and activities i.e. effective communication, decision making, problem solving, understanding of leadership theories and practical application of leadership skills in different settings (Cress, 2001).

- $\quad$ Serve as an agent of positive change at both the classroom level and university level (Harper, 2008).

- Increase peer autonomy, membership to various organizations/clubs, and agencies that lead to higher engagement and academic achievement.

- Help change power dynamics and create new forums for learning how to speak out on their own in a variety of arenas and on a range of issues

- $\quad$ Have a better understanding of self and others

- Wish to show more interest in developing leadership in others beyond the campus

- $\quad$ Show a greater commitment to civic responsibility beyond the university experience

- $\quad$ Gain a sense of personal ethics and clarity of personal values

- $\quad$ Gain improved conflict resolution skills and problem solving at a broader level

- $\quad$ Have ability to gain knowledge and process of better decision-making skills

- $\quad$ Deal better with complex and uncertainties

- $\quad$ Plan and implement programs better

- $\quad$ Take more risk willingly

- Use leadership theories and practices as they continue to develop

Creating visionary student leaders at the university or individuals within an organization for the future could possibly help to improve the quality of life and opportunities for others to grow academically, culturally and socially.

\section{SUMMARY}

Students involved in leadership activities at the university and individuals within an organization learn to demonstrate being mature and self-discipline, positive attitude, resiliency, vision of action, stay goal focused and make revisions when needed. Students who demonstrate strength in their leadership at the university or individuals within an organization will: surround themselves with the best people for the job, learn to delegate authority and require results, model the behavior they expect of others, believe in and inspire positive change, never take one's self too seriously, serve others, not one's self and celebrate success and give credit to others for a job well done.

\section{AUTHOR INFORMATION}

Dr. Ann Hilliard is an assistant professor at Bowie State University U.S.A. in the College of Education, Department of Educational Studies and Leadership. For over ten years, Dr. Hilliard has worked at U.S. universities and colleges. Currently serves as program director for the Principals' Institute at Bowie State University. She has served as an educational consultant for schools in Seoul, Korea; U.S. Virgin Islands; the Bahamas, University of Maryland system, and at Michigan State University. Dr. Hilliard earned her doctorate degree from George Washington University.

\section{REFERENCES}

1. American College Personnel Association (ACPA) 2004 Needham Heights, MA: Simon and Schuster.

2. Astin, A. w. (2004). Achieving education excellence: A critical assessment of priorities and practices in higher education. San Francisco: Jossey-Bass.

3. Bennis, W. (2001). On Becoming a Leader. New York: Addison-Wesley. 
4. Blimling, G. S., Whitt, E. J., \& Associates (2003) Good practice in student affairs: Principles to foster student learning. San Francisco: Jossey-Bass.

5. Fullan, Michael, (2002) Leadership in a Culture of Change, Jossey-Bass http://www.ic.gc.ca/eic/site/csrrse.nsf/eng/rs00139

6. Korn - Ferry, (2009) korn-Ferry International, $5^{\text {th }}$ Edition

7. Kouzes, James and Posner, Barry (2002) Leadership Challenges: Jossey-Bass

8. Pace, C. (2004) Measuring the quality of college student experiences. Los Angeles: University of California, high Education Research Institute.

9. Zimmerman-Oster, K., \& Burkhart, J. (2002) Leadership in the making: Impact and insights from leadership development program in U.S. colleges and universities. Battle Creek, MI: W.K. Kellogg Foundation. 
NOTES 